\title{
EL MONSTRUO DE LAS MIL CARAS: \\ REPRESENTACIONES DEL MONSTRUO \\ Y SU CREADOR EN LAS DISTINTAS ARTES
}

\author{
Laura Cabrera de la Rosa \\ Universidad de La Laguna
}

\section{RESUMEN}

Desde principios del siglo $\mathrm{xx}$, e incluso antes, hemos podido contemplar distintas representaciones del monstruo y su creador, Víctor Frankenstein. Algunas de ellas se asemejan a las características citadas en la novela y otras han bebido directamente del cine. Pero las cuestiones son las siguientes: ¿quién es el verdadero monstruo?, ¿cuáles han de ser las representaciones definitivas de estos personajes? Probablemente nunca lleguemos a tener una única imagen de estos personajes, pero lo que sí sabemos es que forman y formarán parte de nuestro imaginario colectivo.

Palabras Clave: Frankenstein, monstruo, representaciones del monstruo, artes.

\author{
THE MONSTER OF THOUSAND FACES: \\ REPRESENTATIONS OF THE MONSTER \\ AND HIS CREATOR IN THE DIFFERENT ARTS
}

\section{Abstract}

Since the beginning of the 20th century and even before, we have been able to contemplate different representations of the monster and his creator, Victor Frankenstein. Some of them resemble the characteristics cited in the novel and others have drunk directly from the cinema. But the issues are as follows: Who is the real monster? What are the definitive representations of these characters? We will probably never have a single image of them, but we know that they form part and will be part of our collective imaginary.

KeYwords: Frankenstein, Monster, Monster's representations, Arts. 


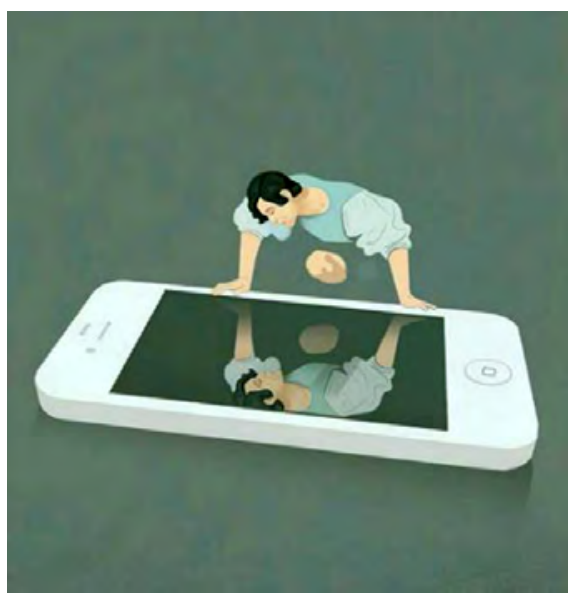

Social media narcissism.

Ilustración del italiano Marco Melgrati*.

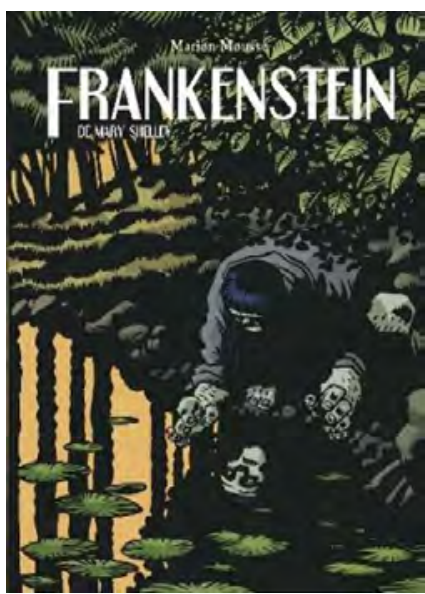

Portada del cómic Frankenstein de Marion Mousse.

En nuestra sociedad la belleza ocupa un lugar estratégico. La imagen lo es todo, incluso por ella podemos obtener un trabajo o no. La cara que mostremos al mundo puede delimitar nuestra existencia, nuestra forma de vida, ya que tenemos unos cánones de belleza y todo lo que se sale de ellos nos resulta impactante e incluso, en ocasiones, nos produce miedo. No olvidemos que desde la Antigüedad existen mitos como el de Narciso, quien no podía dejar de amar su aspecto, lo que se sigue viendo cada día reflejado en publicidad y en las imágenes que nos inundan continuamente. La imagen de Marco Melgrati, que exponemos más arriba, muestra el narcisismo que se puede observar todos los días en las redes sociales. Muchas veces, lo que vemos en ellas es fruto de momentos de máxima artificialidad, para, así, sacar a relucir nuestra mejor cara. Por otro lado, tenemos la portada del cómic de Marion Mousse en la que aparece la criatura contemplando su imagen por primera vez y no por narcisismo, sino para descubrir qué es aquello que tanto temen los que le rodean.

Poco a poco hemos creado una sociedad donde la apariencia nos aporta unos prejuicios por los que nos debemos guiar, desechando el mundo interior que nos pueden ofrecer los demás. Como ya hemos dicho, nuestra imagen o nuestro aspecto físico, en algunas ocasiones, es fundamental para no ser rechazado socialmente. Por este motivo, hemos creído necesario señalar la imagen con la que es representado

* Se puede consultar esta imagen en la cuenta de Instagram de su creador: https://www. instagram.com/p/BAA9amPJSsG/?hl=es\&taken-by=m_melgrati. 


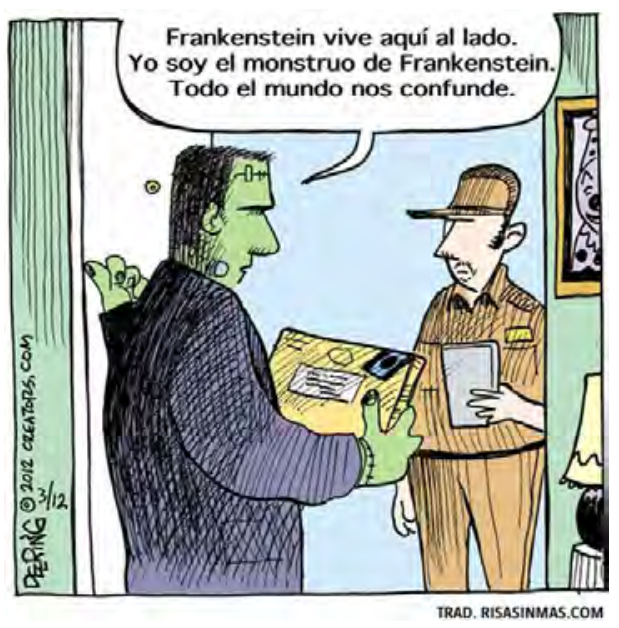

Caricatura realizada en 2012.

el creador y su criatura en las distintas representaciones que se han llevado a cabo de estos personajes de la novela Frankenstein, haciéndose hincapié en los elementos que nos producen rechazo.

¿Cuántas representaciones habremos visto de la criatura y su creador? Quizás miles o quizás millones. El monstruo forma parte de nuestro imaginario. Tanto es así que hasta aparece en publicaciones humorísticas como esta, en la que se señala uno de los errores más frecuentes en torno a este personaje: confundir el nombre de su creador con el de la criatura, que, como sabemos, nunca obtuvo ningún apodo o denominación.

Quizás la imagen más conocida para todos sea la de Boris Karloff encarnando el personaje de la criatura en el filme dirigido por James Whale (1931). Sin embargo, esta imagen, que tan integrada tenemos en nuestro imaginario, dista bastante de la que pretendió plasmar Mary W. Shelley en su obra.

A continuación, reflexionaremos sobre las imágenes más relevantes de la criatura, comparando sus diferentes aspectos con los que se describen en la novela. Sin duda, observaremos una clara influencia de otros medios artísticos, ya que el cine ha marcado nuestra percepción, pues es uno de los lenguajes más visuales y el primero en caracterizar al personaje principal de la obra. Por otra parte, también destacaremos la caracterización que recibe el creador, ya que, según el momento histórico en el que haya sido interpretado o reinterpretado este personaje, veremos un ideal de belleza totalmente distinto. Recordemos que entre el monstruo y el creador hay una conexión bien clara y no se establece por el momento de la creación, sino porque en el fondo son los contrarios perpetuamente unidos por las circunstancias. El monstruo siempre representará el horror o la fealdad, mientras que su creador representará la belleza, aquella que es aceptada socialmente. 

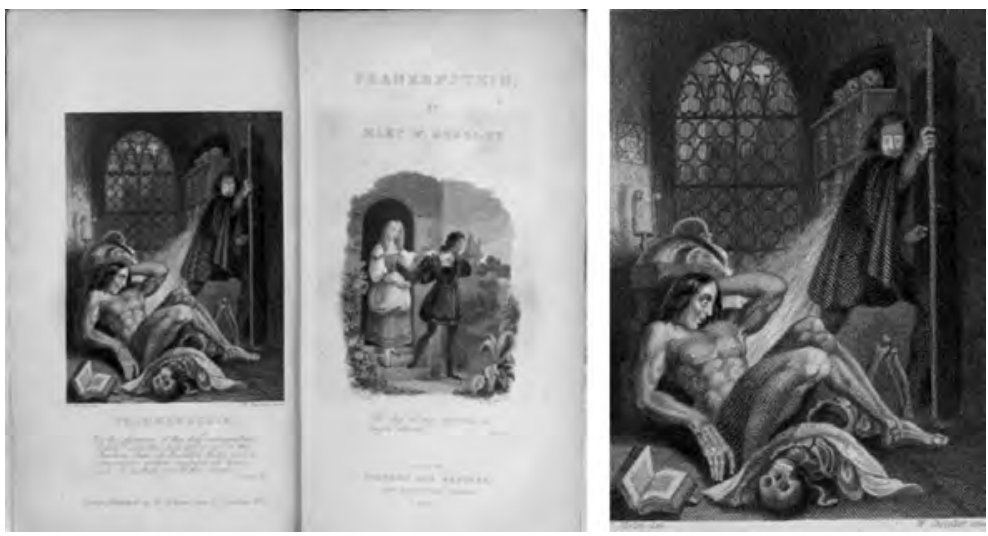

Grabados que acompañan a la edición de 1818 de Frankenstein.

\section{EL MONSTRUO EN LA NOVELA}

Sus miembros estaban bien proporcionados; y había seleccionado unos rasgos hermosos para él. ¡Hermosos! ¡Dios mío! Su piel amarillenta apenas cubría la obra de músculos y arterias que quedaba debajo; el cabello era negro, suelto y abundante; los dientes tenían la blancura de una perla; pero todo ello no hacía sino contrastar espantosamente con unos ojos aguanosos que parecían casi del mismo color blancuzco que las cuencas que los alojaban, una piel apergaminada, y unos labios estirados y negros (2011: 85-86).

Así es como Mary W. Shelley describe a la criatura. Nos la presenta con unas características que distan mucho de las que le otorgaríamos a un ser hermoso. Sin embargo, su creador es capaz de ver la belleza en el horror. Recordemos que a pesar de que la obra está ambientada en el siglo XVIII, es creada en el XIX, una época donde se desarrolla un movimiento como el Romanticismo, en el cual se ve belleza en el lado más oscuro o terrible de la naturaleza ${ }^{1}$, con lo cual es comprensible que la autora se viera influida por esa tendencia a mostrar lo bello en lo sublime.

Hemos añadido fotografías de los grabados que aparecen en la edición de Frankenstein de 1818. Si nos fijamos, a pesar de que no tienen color y no podremos apreciar el tono de la piel del monstruo, podemos observar que se parece bastante a la descripción que aporta la autora en la novela. Posee el pelo largo y negro, unos

${ }^{1}$ Podemos ver ejemplos de lo sublime, sobre todo, en la pintura. Obras como las de Théodore Géricault (La balsa de la Medusa), William Turner (Steam-Boat off a Harbour's Mouth in Snow Storm), Johann Heinrich Füssli (La pesadilla) o Caspar David Friedrich (Abadia en el robledal) muestran la belleza de lo sublime de la naturaleza. 

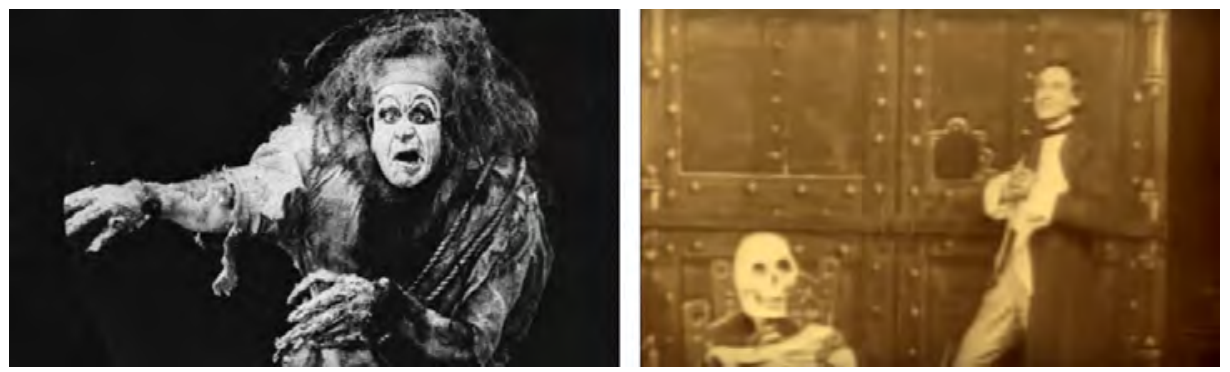

Imágenes de la película Frankenstein de 1910.

ojos grandes, un cuerpo de proporciones anormales, labios negruzcos, y se pueden apreciar bastante los músculos y los tendones debajo de la piel de la criatura.

Por otro lado, podemos ver la imagen de Víctor Frankenstein y Elizabeth Lavenza. Sin duda, ambos poseen rasgos bellos, sobre todo ella, que encaja en el ideal de belleza de mujer, rubia y con facciones angelicales. Por su parte, Frankenstein también encajaría en el ideal de belleza del siglo XviıI, un hombre de cabello largo.

\section{EL MONSTRUO EN EL CINE}

La novela Frankenstein tiene muchísimas adaptaciones al cine. Hemos hecho una selección de 10 películas, las que más interés nos han suscitado. Por ello, solo trabajaremos con las imágenes creadas para estas versiones.

Comenzaremos con una de las más antiguas, la de 1910, dirigida por J. Searle Dawley. Si nos fijamos en el monstruo, podríamos decir a priori que sus rasgos coinciden con la descripción que se hace en la novela. Como la película es muda y en blanco y negro, hay otros aspectos que no podríamos tratar, como, por ejemplo, el color de su piel o si se expresa con gruñidos, tartamudea o habla de forma clara. Sí que podemos resaltar que posee una melena larga y oscura, que viste con harapos, sus manos son de un tamaño exagerado, parece estar jorobado y su rostro es blanco, resaltando un contorno negro que rodea sus ojos.

En cuanto a su creador, hemos de decir que su imagen es similar a la que aparece en el grabado del libro de 1818, pero con el cabello más corto. Sin duda, es el prototipo de belleza del hombre de inicios del siglo xx. Un hombre afeitado, de piel morena y pelo oscuro.

En segundo lugar, tendríamos la versión cinematográfica más conocida de la novela, Frankenstein de James Whale (1931). Si nos fijamos bien en la criatura, podemos ver que no se parece en demasía con la descripción que se da del monstruo en la novela. Posee una cabeza y un cuerpo bastante desproporcionados. Esto último podría ser similar a la obra de Shelley, pero el gran número de grapas que 


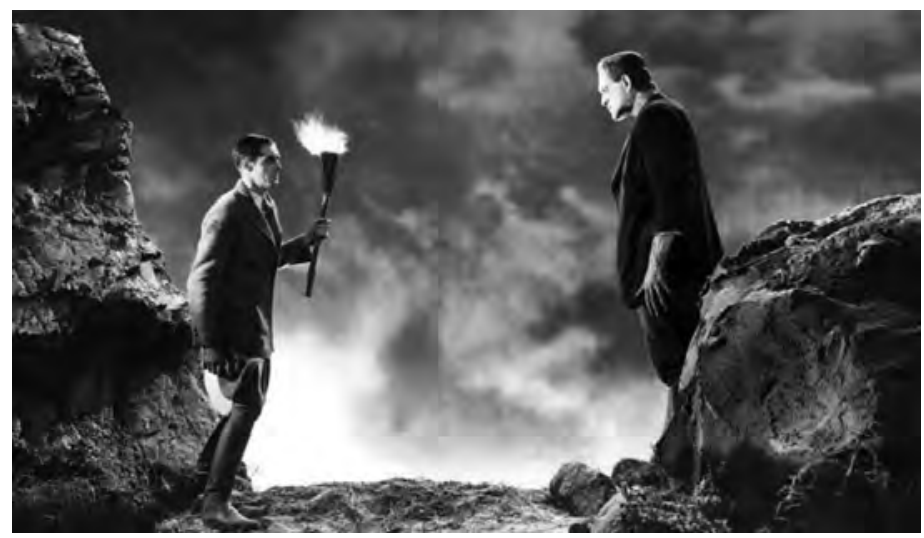

Encuentro creador-criatura en la película Frankenstein de 1931.

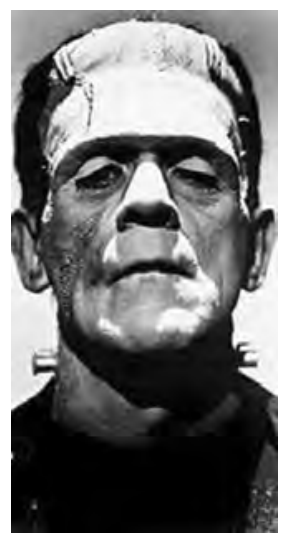

Imagen del monstruo.

tiene en su rostro o los tornillos del cuello no se mencionan en ningún momento en la novela. Este último ańadido (los tornillos) tiene su origen en la pregunta de cómo pudo Frankenstein transmitir la electricidad a lo largo del enorme cuerpo de la criatura. Claramente, una buena fuente de transmisión de la electricidad es el metal, de ahí se puede intuir que se hayan empleado estos tornillos. Por otra parte, su vestimenta no coincide con la de la novela, puesto que viste de negro, con pantalones y chaqueta, muy del estilo de los ańos 30. Como con el anterior filme, no podemos apreciar el color de la piel del monstruo, puesto que es una película en blanco y negro, pero sí que podemos notar detalles que con el anterior ejemplo eran imposibles. Uno de ellos, de vital importancia, es que el monstruo puede expresarse y lo hace en la gran mayoría de ocasiones mediante gruñidos. Es un monstruo sin capacidad de crear un discurso completo, con coherencia y cohesión. Esboza algunas palabras, pero nunca llega a tener una conversación plena con ningún personaje.

En cuanto a Frankenstein, tanto su vestimenta como su peinado concuerdan con el estilo o el canon de belleza existente en los años 30. No olvidemos que la película parece estar ambientada en esa época, en lugar de en el siglo XVIII. En nuestra opinión, trasladando la acción a esa época, se crea una atmósfera de verosimilitud, mucho más que si fuera adaptada a la que corresponde a la novela. En estos momentos, se buscaba impresionar al espectador y con esta película lo consiguieron ${ }^{2}$.

En tercer lugar, hemos creído conveniente ańadir su secuela, La novia de Frankenstein, de 1935, dirigida por el mismo realizador. Podemos observar que la

\footnotetext{
2 Se recomienda el visionado de la película Dioses y monstruos, en la que se puede ver el origen del filme Frankenstein de 1931.
} 


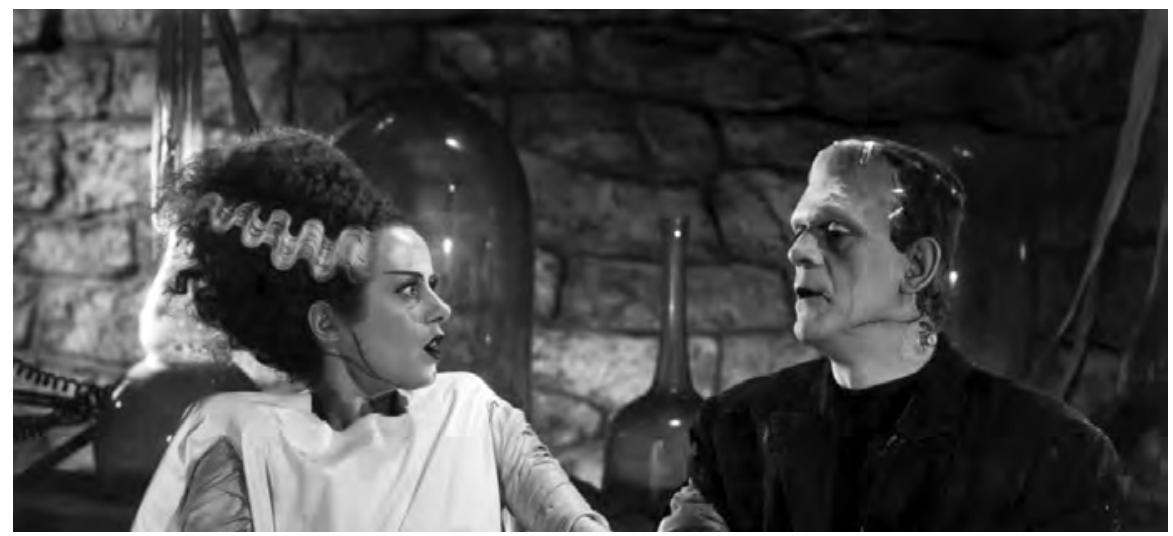

Encuentro de la novia y el monstruo.

imagen del monstruo es la misma que en la de 1931, aunque en esta película consigue decir más de dos palabras seguidas. Además, se añade una nueva imagen, que se ha convertido en un icono con el paso de los años, la de su novia. Se puede observar a una joven con unos rasgos similares a los del monstruo, pero que parece ser más hermosa que la primera creación. Uno de ellos es su pelo alargado y las rayas blancas que adornan la oscuridad de su melena ${ }^{3}$.

En cuarto lugar, nos interesa la representación del monstruo de la película de 1957 La maldición de Frankenstein. Como bien podemos observar, la imagen del personaje es mucho más putrefacta que las versiones anteriores. Se debe a que recogen el cadáver de una horca (porque es el cuerpo de un criminal ajusticiado) y que los cuervos ya habían comenzado a comérselo. Al igual que en las películas de Whale, va vestido de negro y tiene el pelo corto y negro. La criatura no habla en ningún momento, se expresa mediante gruñidos e intenta matar o golpear a toda persona que se interponga en su camino. Los instintos asesinos del anterior ser que poblaba aquel cuerpo siguen vigentes en la nueva vida de este monstruo. Además, podemos contemplar que está envuelto en vendas, como ocurría con la novia de la criatura en la versión de 1935.

En cuanto a la imagen de Frankenstein y de su profesor, es muy similar a la que podría llevar cualquier hombre de los años 50, tupés con volumen. Sin embargo, hemos de señalar que el carácter de Frankenstein en esta película roza la psicopatía, solo le importa experimentar y conseguir sus metas, incluso llega a acabar con la vida de los demás si se interponen en sus objetivos.

3 Algunos estudiosos señalan que esta imagen es la inspiración para el cabello alargado y azul que posee Marge Simpson de la serie animada Los Simpson. 


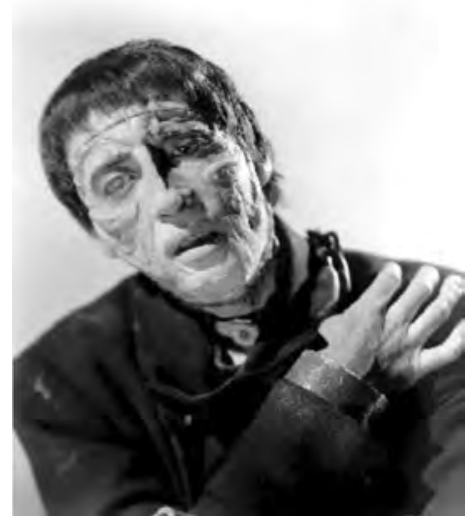

La criatura.

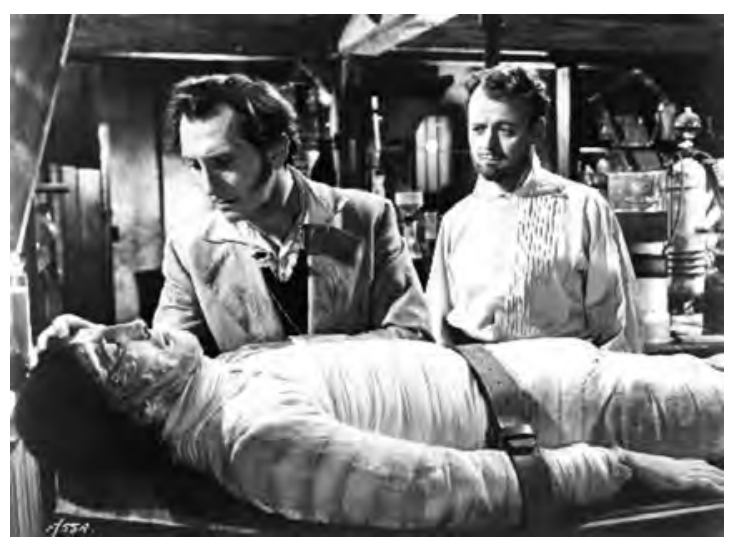

Instantes después del intento de darle vida al cadáver.

En quinto lugar, tenemos otra adaptación realizada por el mismo director, en la que se da protagonismo a la mujer. Recordemos que estas dos películas no tienen que ver en nada con la novela de Mary W. Shelley. Simplemente, se emplea la obra de esta autora como inspiración para estas nuevas creaciones.

Esta película de 1967, Frankenstein creó a la mujer, es la secuela de la anterior. Sin embargo, es importante porque la imagen de la mujer que crea el doctor es totalmente distinta a la de Whale. Recordemos que el cuerpo que emplea esta vez para su experimento es el de una mujer que se ha suicidado por haber perdido al amor de su vida, convirtiéndose en toda una femme fatale cuando regresa del más allá, pues su único anhelo es matar a todos aquellos que hicieron que su amante fuera guillotinado.

Si nos fijamos en su imagen antes de morir, se trata de una muchacha que tiene miedo a mostrar la quemadura de su rostro y tiene el pelo de color castaño. Después de resucitar, le cambian el color a rubio y la operan para que su rostro se vuelva hermoso. En cuanto a su peinado, podemos observar que es bastante elevado, muy similar al que poseía la novia de la película de Whale, pero con toques de los años $60^{4}$.

En sexto lugar, tendríamos la comedia El jovencito Frankenstein, de 1974. A pesar de ser una parodia de la película de 1931, los personajes distan mucho del aspecto físico que tienen los de dicho filme. También, hemos de tener en cuenta que es una película hecha y ambientada en los años 70, con lo cual es lógico que los personajes encajen en los peinados o formas de vestir de la época.

${ }^{4}$ La productora Hammer se dedicó entre los años 30 y 70 a hacer películas «de género», con abundantes versiones de Drácula y Frankenstein. 


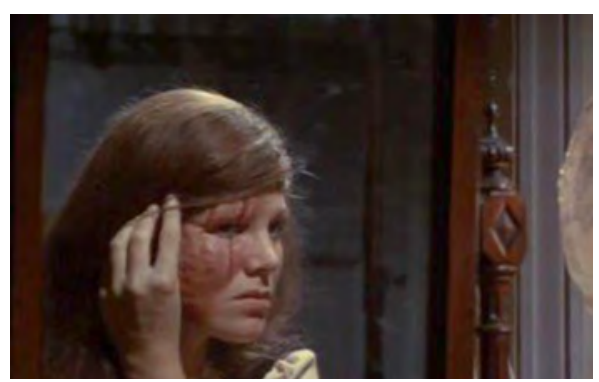

Cristina antes de suicidarse.

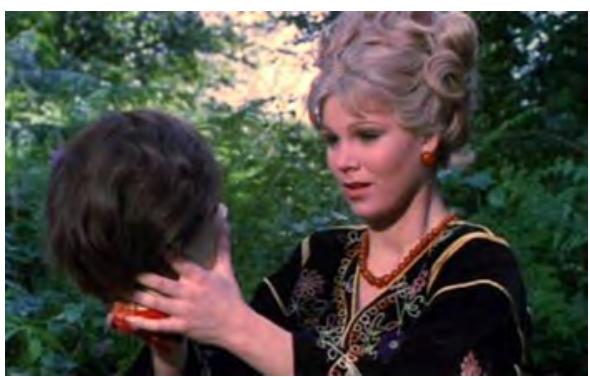

Cristina después de volver a la vida.

El doctor Frankenstein es rubio, con los ojos claros y viste y se peina acorde al momento histórico en el que se desarrolla la historia. Por otra parte, tendríamos al monstruo, que físicamente es bastante similar a la película parodiada, pero que en esta ocasión se le da la oportunidad de expresarse e incluso de cantar. Todos los personajes son exagerados, con características llamativas para hacer la obra aún más cómica, lo que se puede observar de forma más clara en el personaje de Igor, puesto que es la clave para el humor en el filme, y sus rasgos físicos, como, por ejemplo, la joroba de su espalda, están bastante hiperbolizados. Sin duda alguna, se nos muestra la cara más amable de los personajes de Frankenstein y su criatura, a pesar de que ninguno de los dos coincida con las descripciones que aporta Mary W. Shelley en su novela.

En séptimo lugar, en las imágenes de la película La prometida (1985), en la que vemos plasmada la imagen del creador, la criatura y la novia. Por el contrario que alguna de las anteriores, la vestimenta que llevan los personajes coincide con la época que se representa en la novela.

Si nos fijamos en el personaje de Frankenstein, podemos ver que es un hombre rubio con melena, un hombre bello. Por el contrario, su criatura porta una gran cicatriz en la cabeza y no se adapta a los cánones de belleza. Es un ser de dimensiones grandes, como indicaba la novela, pero posee una media melena castańa y no se pueden apreciar más detalles que nos describía la autora en la obra. Sin embargo, es un ser que posee sensibilidad y es capaz de hablar, aunque sin tener una competencia lingüística plena.

En cuanto a Eva, la novia, no parece un cadáver al que se le ha dado una segunda oportunidad de vivir. Es una mujer hermosa e inteligente que es capaz de adaptarse rápidamente a la vida en sociedad.

En Remando al viento (1987), a pesar de no contar la historia del creador y la criatura, nos muestra un esbozo de cómo era la vida de Mary W. Shelley un poco antes del proceso creador, en pleno proceso y posteriormente a este. Se destaca la relación entre el monstruo y la autora. Por ello, es importante mostrar cómo se caracteriza a este personaje. 


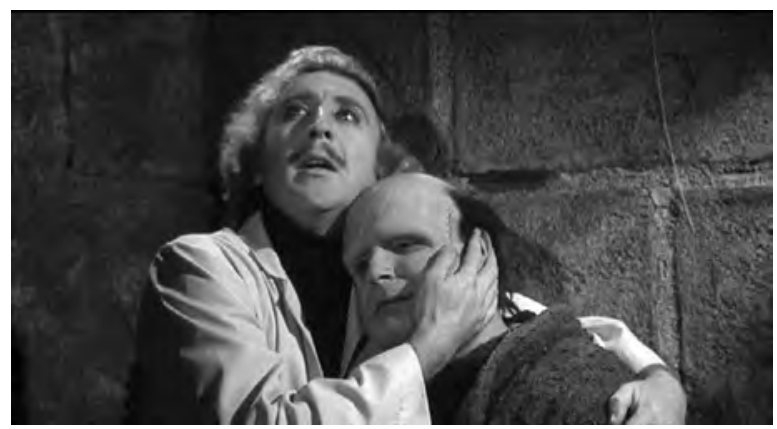

Creador y monstruo.

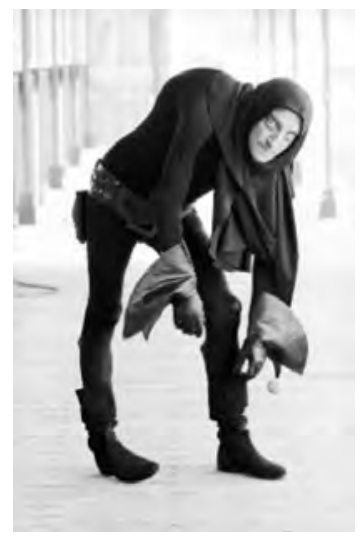

Igor, ayudante de Frankenstein en El jovencito Frankenstein (1974).

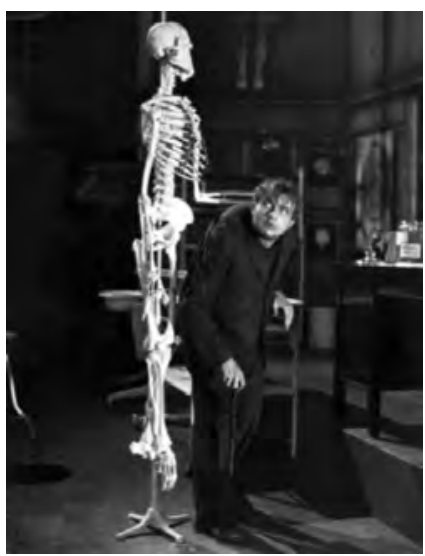

Fritz, ayudante de Frankenstein en la versión cinematográfica de James Whale, Frankenstein (1931).

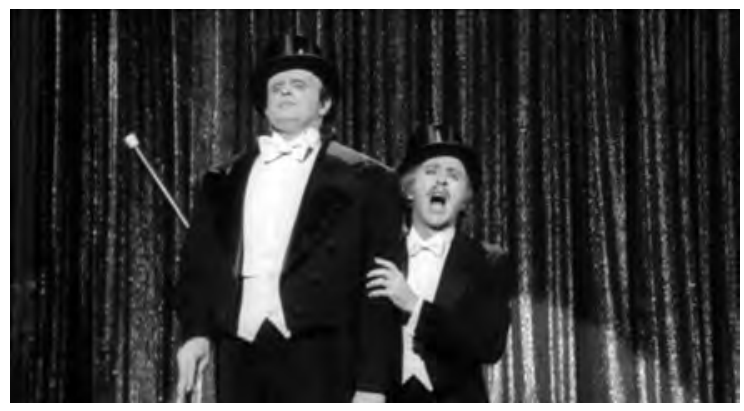

Creador y criatura bailando en un espectáculo.

Se nos presenta a un hombre de proporciones grandes, cara alargada y pálida, con ropajes dañados, pero que podría llevar una persona del siglo XIX. Su melena es corta y sus labios oscuros. Aparentemente mantiene casi todas las características que aporta la autora en su novela e incluso es un ser capaz de mantener una conversación, de hablar con la escritora sin necesidad de gestos o gruñidos, tal y como lo haría la criatura que creó el Frankenstein literario.

En Frankenstein de Mary Shelley (1994) podemos observar cómo el personaje de Frankenstein encaja en el canon de belleza de los 90, es un hombre musculado, rubio y de ojos claros. Por la parte que concierne al monstruo, hemos de reseñar que en esta película se han exagerado bastante las cicatrices, las partes en las que 


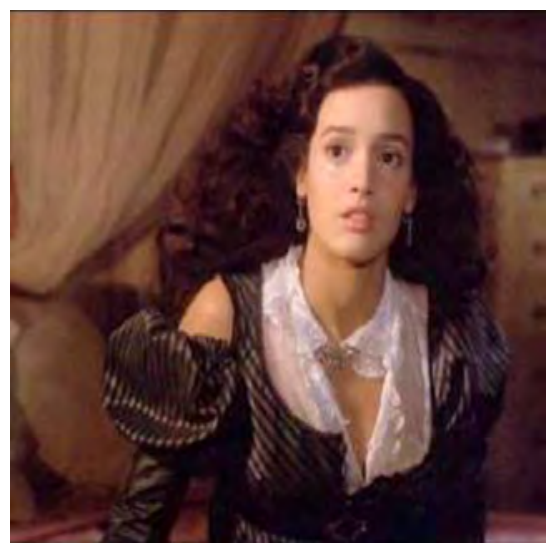

La novia (Eva).

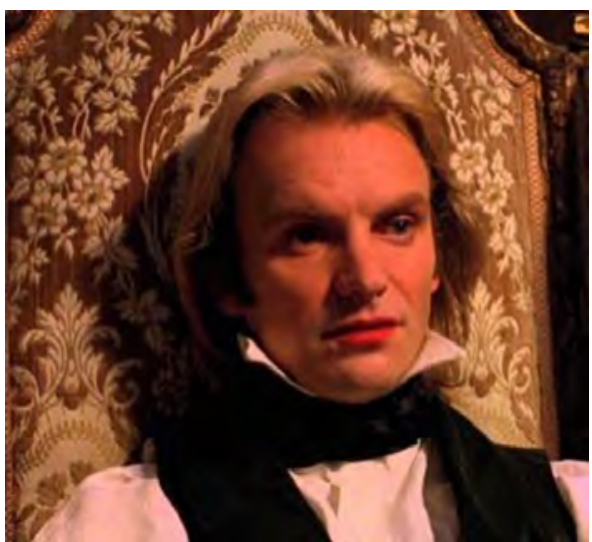

Frankenstein.
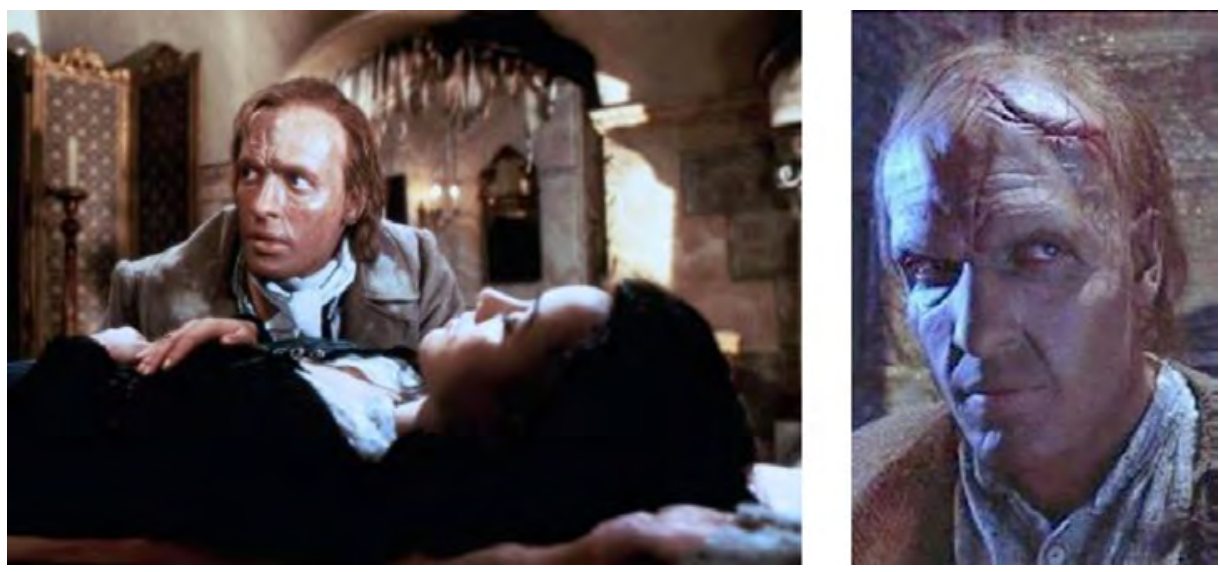

La criatura.

se le ha cosido. Esto crea en el espectador repulsión. El monstruo fue recreado de esta manera para que se rechazara desde el primer momento por su aspecto físico, pero es inteligente y sabe lo que quiere. Su único cometido es vengarse de su creador, el rencor es predominante en este personaje.

En Victor Frankenstein, de 2015, el protagonista es el ayudante de Frankenstein, Igor. Igor es jorobado, pálido, de complexión pequeña y con una melena negra. Posteriormente, gracias a la ayuda del doctor Frankenstein, deja de ser jorobado y 

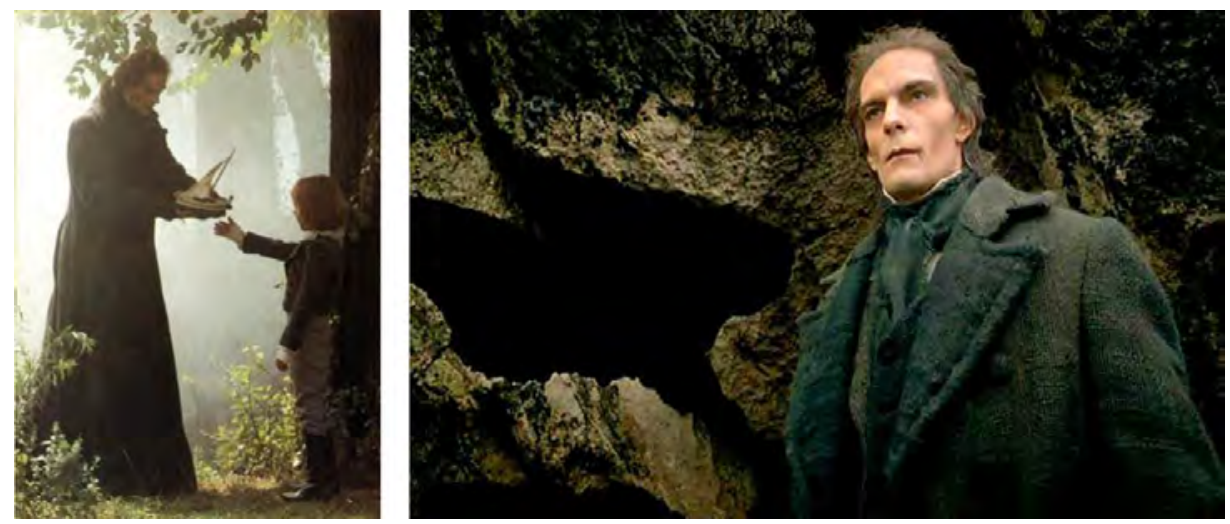

La criatura en distintas escenas de Remando al viento.

empieza a vestir de otra manera, ya que anteriormente acostumbraba a vestir solo para las actuaciones del circo.

Por su parte, Frankenstein es moreno y con ojos azules, con un peinado que podría llevarse en el año 2015, a pesar de realizarse la acción en el siglo XIX. Sin duda, encaja en el canon de belleza más actual. Como en las anteriores versiones, representa lo bello, frente a la deformidad del monstruo.

En cuanto al monstruo, recordemos que es creado a través del cuerpo del hermano fallecido de Frankenstein. Pretendía ser una creación perfecta, un hombre perfecto. Para ello, se crea a un ser con dos pares de pulmones y dos corazones. Tiene muchas cicatrices, grapas en la cabeza (pues se ha tenido que abrir el cráneo para introducir el cerebro), labios oscuros, musculatura trabajada y unas proporciones fuera de lo normal, midiendo más de dos metros. Centrándonos en su conducta, hemos de señalar que no habla en ningún momento y que su primer instinto es matar a todo ser humano que ve.

Estas son solo algunas de las representaciones que hay en el cine, hay muchísimas más ${ }^{5}$. Pero si algo nos queda claro es que cada personaje se adapta a cada momento de creación, ya sea al canon de belleza o adaptando las características del monstruo para causar el mayor horror en el espectador, pues hemos de recordar que el ser humano, con el avance del cine, va perdiendo el asombro o el miedo a lo desconocido, siendo todo muy diferente a los inicios de este arte, cuando una persona se asombraba de todo lo que aparecía en la gran pantalla.

${ }^{5}$ Algunas versiones que no hemos seleccionado podrían ser Life without a soul, de Joseph Smiley (1915); Il mostro di Frankenstein, de Eugenio Testa (1921); Son of Frankenstein, de Rowland V. Lee (1939); House of Frankenstein, de Erle C. Kenton (1944); etc. 


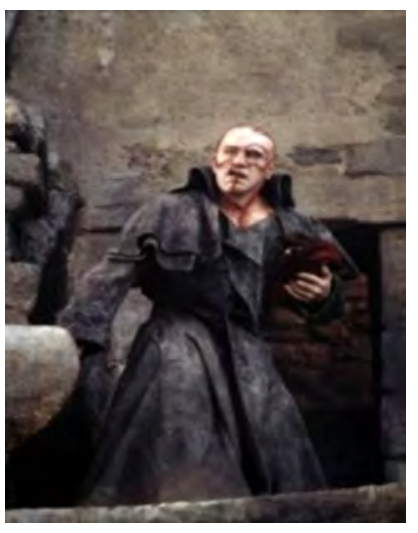

Criatura.

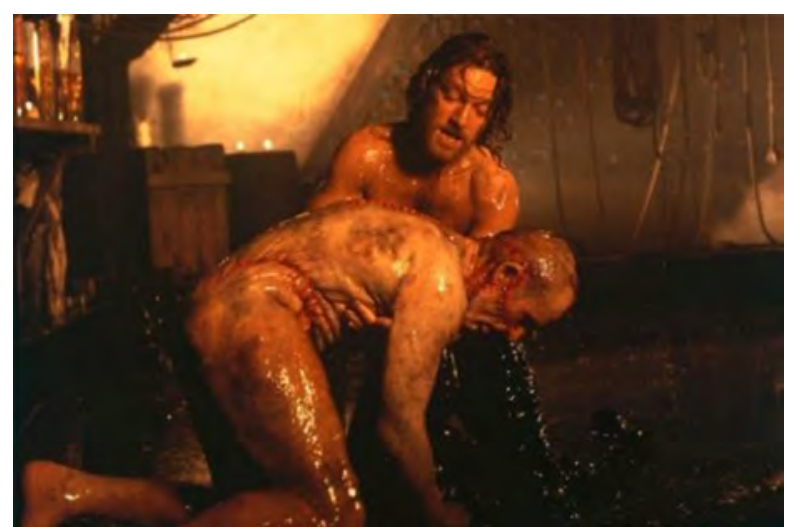

Momentos después de la creación del monstruo.

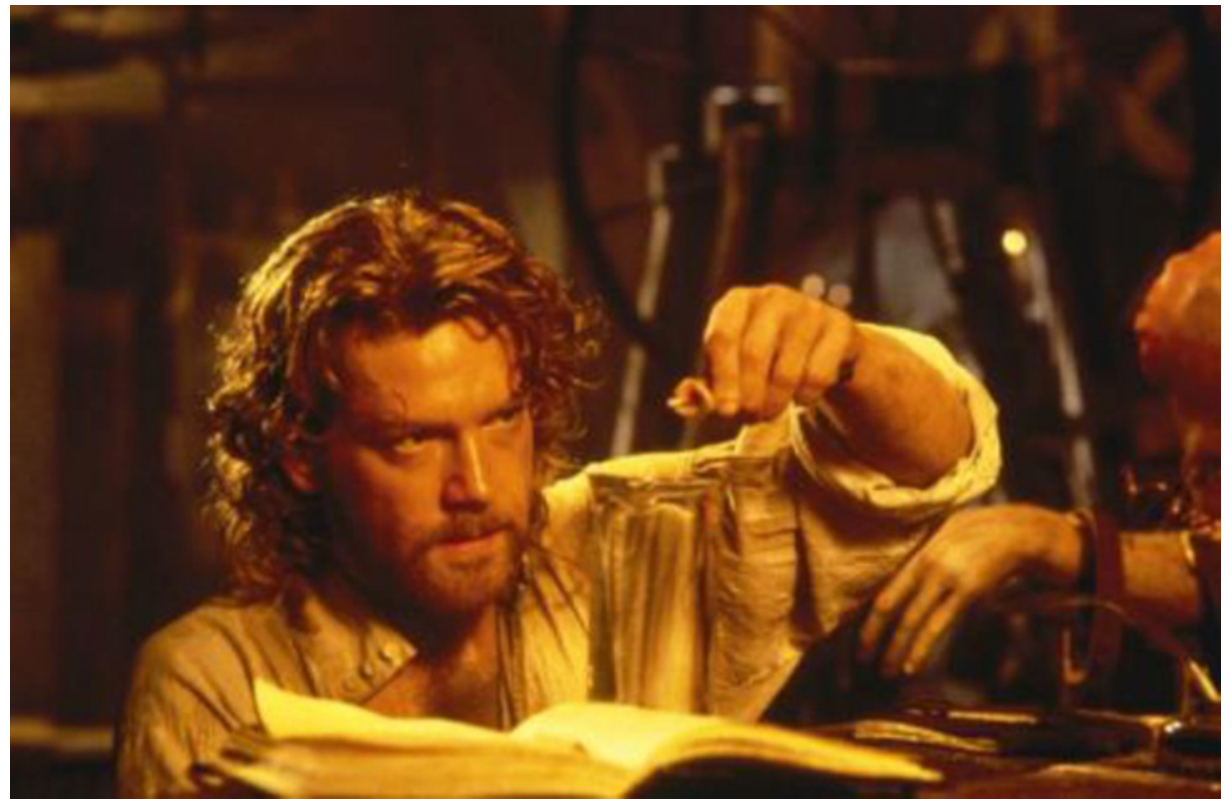

Víctor Frankenstein. 


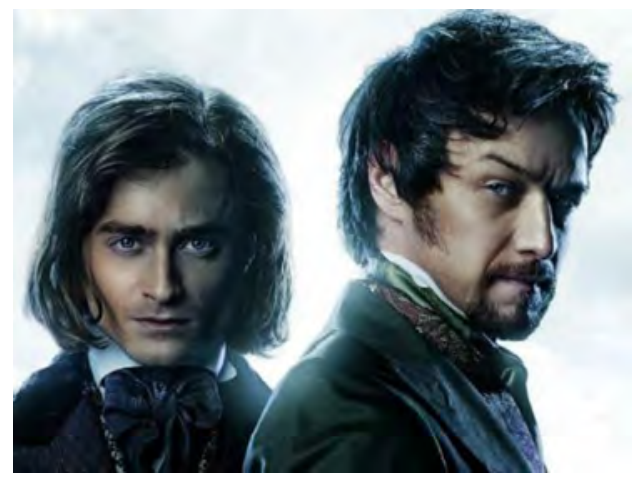

Igor y Frankenstein.

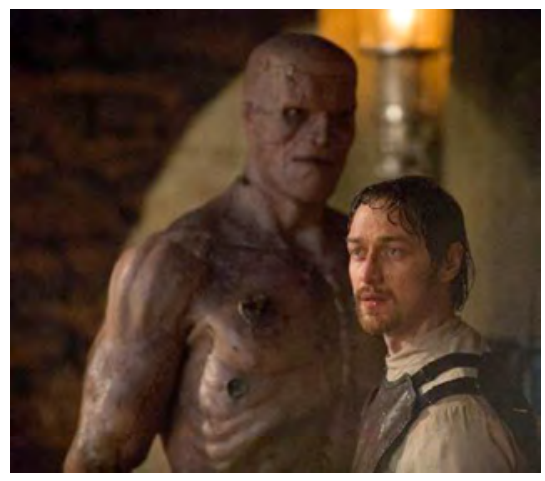

La criatura y su creador.

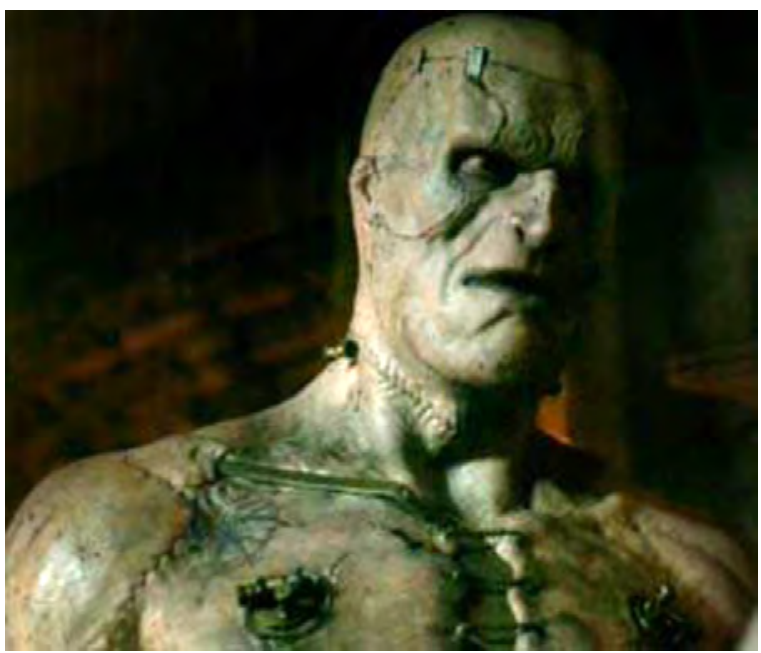

La criatura.

\section{EL MONSTRUO EN EL CÓMIC Y LA NOVELA GRÁFICA}

En los últimos años, ha habido un auge del lenguaje del cómic y la novela gráfica. Por ello, es de vital importancia destacar cómo se plasman los personajes en este medio visual y textual. Al igual que ocurre con el cine, es muy posible que haya muchísimas más adaptaciones de la novela de las que nosotros hemos selec- 


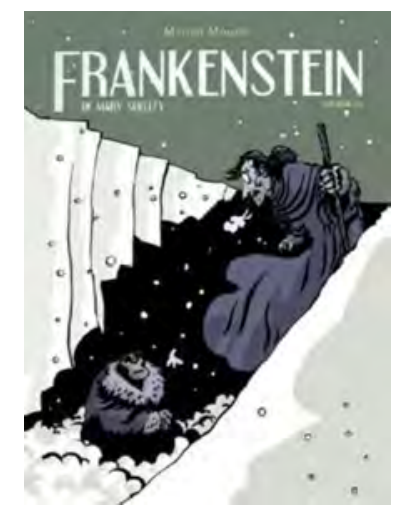

Imagen extraída del cómic.

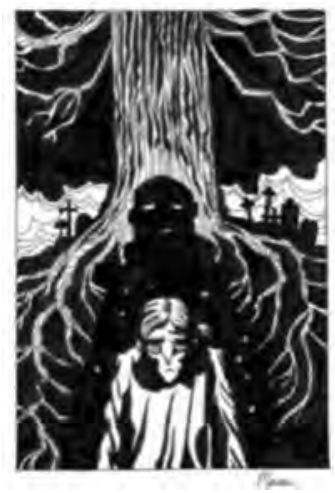

Boceto de la obra realizado por Mousse.
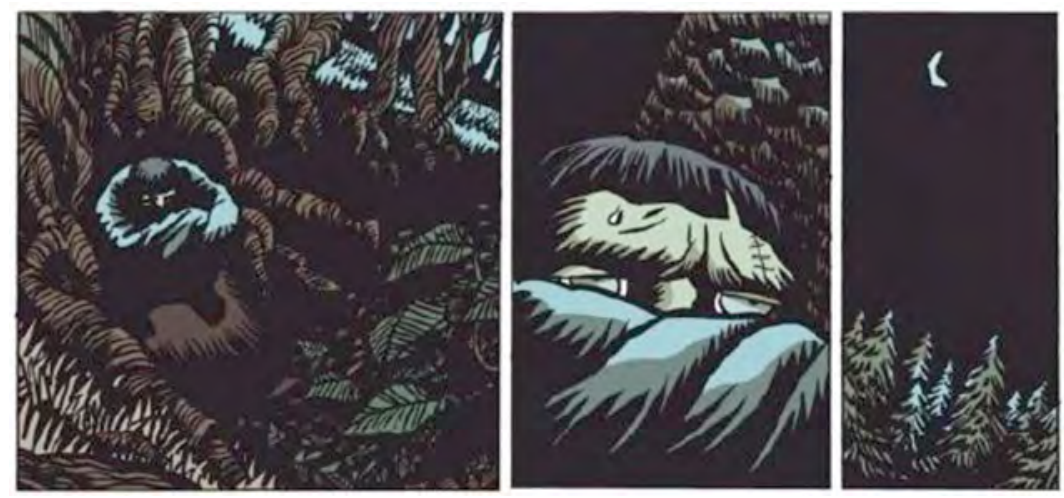

Monstruo.

cionado $^{6}$, en este caso seis, pero hemos querido centrarnos en aquellas obras en las que se captara la esencia del libro y no aquellas en las que se emplea al personaje del monstruo para crear nuevas aventuras.

${ }^{6}$ Hay muchas más versiones en cómic; entre las más destacadas tendríamos las siguientes: Frankenstein, de Dick Briefer, publicado por Prize Comics (años 40); Embalming-The Another Tale of Frankestein, de Nobuhiro Watsuki (2007); Frankenstein, de Tony Tallarico y publicado por Dell Comics (años 60); etc. 


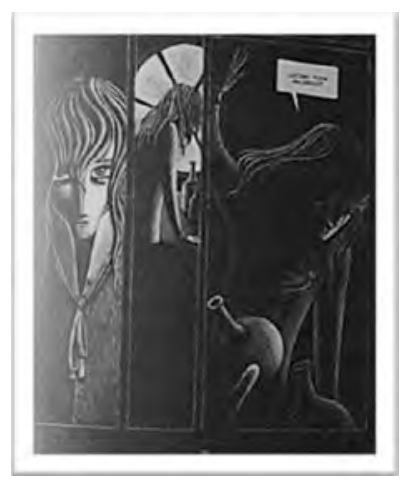

Frankenstein.

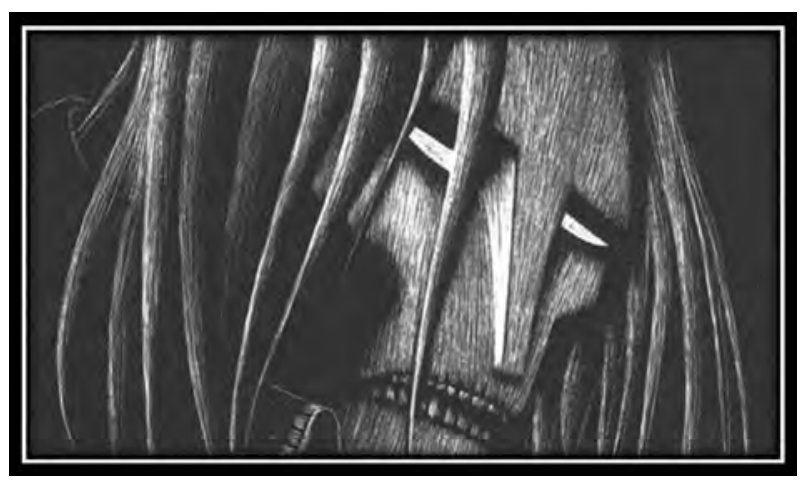

La criatura.

En primer lugar, tendríamos la obra de Marion Mousse de 2009, Frankenstein. Si nos fijamos en el monstruo, su piel es de un color verdoso, es de dimensiones grandes, con ojos claros, pelo negro corto y viste con ropa de abrigo. Su imagen no coincide mucho con la aportada en la novela, salvo en el color del pelo y las grandes dimensiones. Por su parte, Frankenstein podría encajar perfectamente con la imagen de un hombre del siglo xvint, pues posee pelo largo y castaño, es delgado y en todo momento se le retrata con una mirada triste. Hemos de indicar que, en esta ocasión, no se busca la belleza del personaje, viéndose una evolución física a lo largo de la obra, ya que conforme va sucediendo la acción, Frankenstein va enfermando, apreciándose una palpable decadencia física (dejadez de la barba, delgadez, etc.). En cuanto a la personalidad de los personajes, se puede observar a un Frankenstein obsesionado con la idea de la vida y la muerte, tal y como ocurre en la novela. El monstruo es muy sensible y su único objetivo es encontrar a alguien con quien compartir el resto de su existencia. Es capaz de tener una conversación completa, sin equivocaciones gramaticales o gruñidos. Por tanto, se trata de un ser inteligente que se vuelve rencoroso porque su creador no le da lo único que le pide, una compañera.

En segundo lugar, el Frankenstein (2009) de Sergio A. Sierra y Meritxell Ribas. Meritxell Ribas ilustra a los personajes con la técnica del grattage 7 . Por ello, se pueden apreciar las pequeñas franjas de la madera empleada para estas creaciones, lo que dota de profundidad al dibujo. No cabe duda de que estas representacio-

7 Técnica pictórica surrealista que consiste en raspar o rascar los pigmentos de pintura ya secos sobre la superficie de madera o lienzo. Los efectos logrados dependen de la intensidad del rascado y del grosor de las distintas capas de pintura. Como herramientas para efectuar los rascados se utilizan cuchillas, punzones, distintos tipos de lijas, etc. 


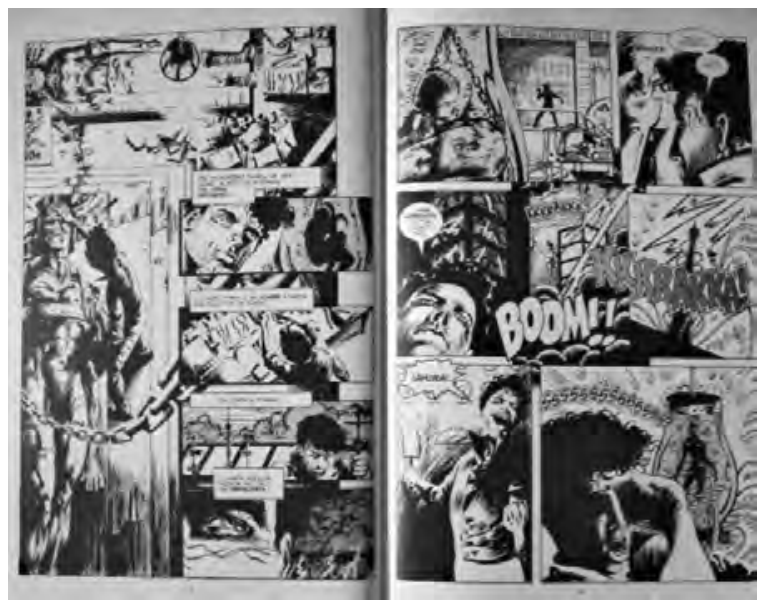

Momento de la creación del monstruo.

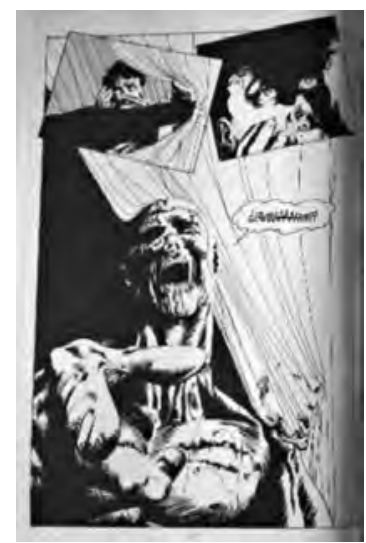

Monstruo poco después de su creación.

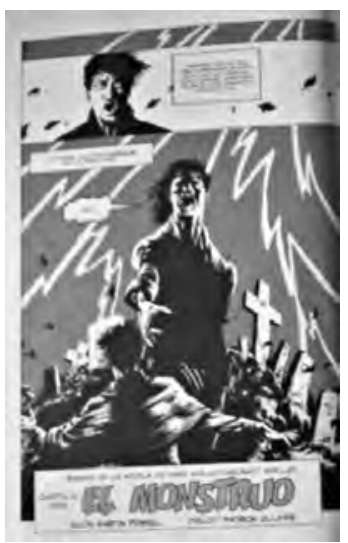

Primer reencuentro con el monstruo.

nes no tienen nada que ver con las anteriores, puesto que la ilustradora emplea formas geométricas para conformar los rostros, lo que se puede apreciar en las narices. El monstruo se caracteriza con los mismos rasgos que Mary Shelley expone en su obra. Es un ser de grandes dimensiones, con pelo largo y negro, labios negruzcos y piel clara. No sabemos si la piel sería amarillenta o no, ya que se trata de un cómic en blanco y negro. Al igual que ocurre con los anteriores cómics, el monstruo es un ser sensible e inteligente, capaz de desarrollar sin problemas una conversación. 


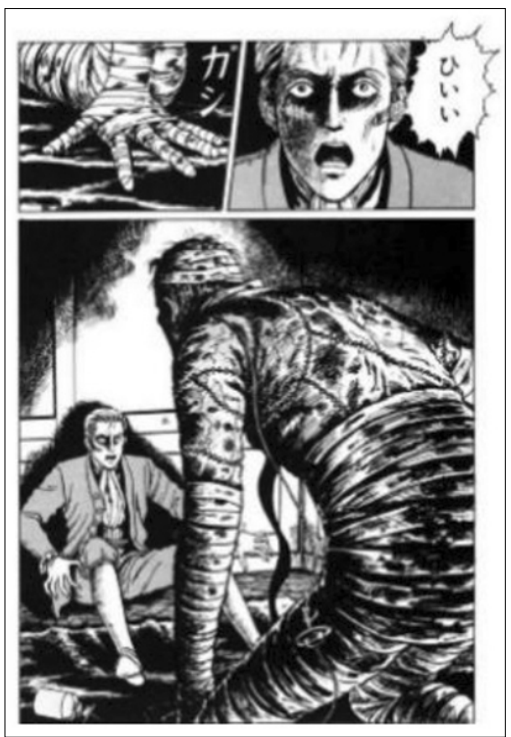

Encuentro de Frankenstein y el monstruo.

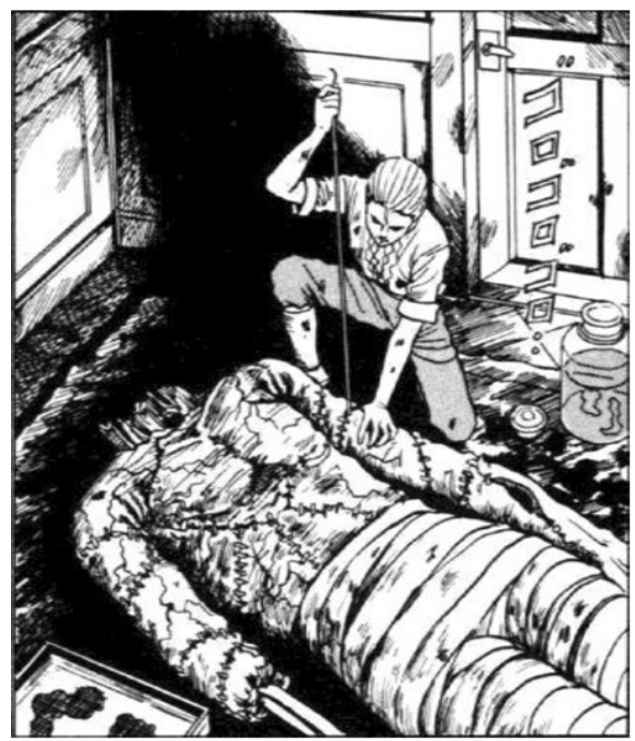

Proceso de creación.

Frankenstein tiene rasgos hermosos, lo que hace destacar las diferencias físicas entre monstruo y creador. Posee una melena larga, que suele aparecer suelta en la mayor parte de la obra, ojos oscuros y ropa acorde al siglo XviII. En cuanto a su forma de ser, hemos de decir que es un ser bastante atormentado, obsesionado con conseguir el objetivo de crear una nueva forma de vida.

En tercer lugar, estudiamos el Frankenstein de Martin Powell y Patrick Olliffe. Como podemos observar, el estilo de dibujo es muy diferente a los anteriores. Sin embargo, el monstruo concuerda bastante con la descripción de la novela. Es un ser de complexión grande, de melena negra y larga (aunque en el momento de su creación no tiene pelo), con una boca negruzca. Sin embargo, como ocurre con otras adaptaciones de la imagen del monstruo, se hace mucho hincapié en las cicatrices o heridas que porta. En cuanto a su personalidad, es similar a la de los anteriores.

Frankenstein tiene rasgos bastante masculinos, un mentón ancho, pelo oscuro, corto y rizado, así como una complexión delgada. Su imagen nos recuerda mucho a otros cómics donde los personajes son americanos; por ejemplo, a Superman. Viste tal y como se vestiría en el siglo XviII. Su única obsesión es la muerte y tiene pesadillas con ver muertos a sus seres queridos. En nuestra opinión, es un personaje al que le afecta mucho la muerte, desde la pérdida de su madre.

El Frankenstein (2016) de Junji Ito es una versión manga de la obra, donde los personajes poseen rasgos bastante exagerados y sangrientos, sobre todo en lo que 


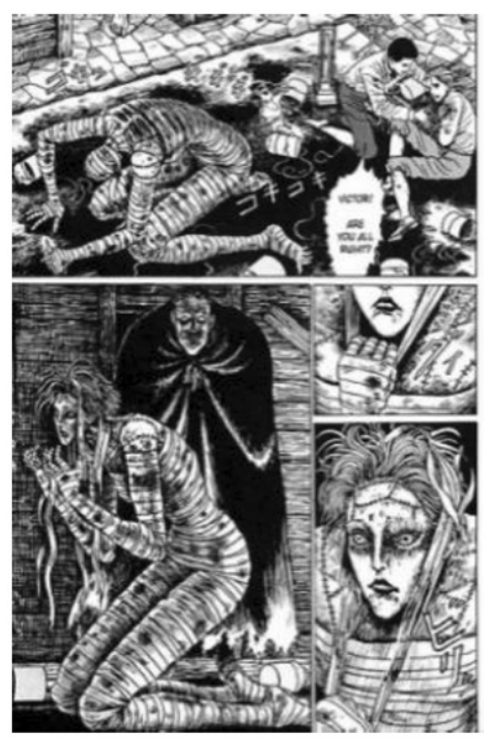

La novia.

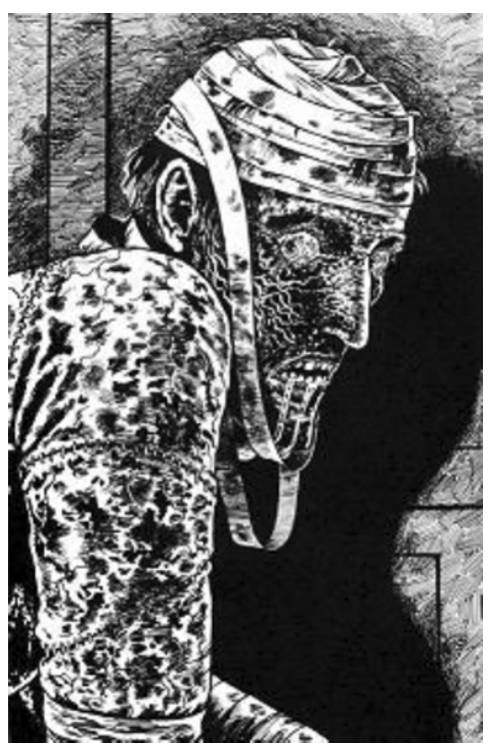

El monstruo.

concierne a los monstruos. Frankenstein y su familia son los únicos personajes que no son retratados de forma sangrienta o gore, salvo cuando fallecen.

Frankenstein aparece representado como un hombre rubio y de constitución y facciones delgadas. Viste como una persona del siglo XVIII o XIX en todo momento de la obra. En cuanto a los monstruos, tanto la novia como el monstruo aparecen representados como si fueran momias egipcias, envueltos en vendas. El monstruo es bastante más vengativo que los anteriores, roza el cinismo, pues pide que se incorpore la cabeza de Justine al cuerpo de su nueva compañera. La novia, por su parte, tiene el rostro de Justine, pero ha perdido el aspecto anterior, dándosele una imagen un tanto demoníaca. El monstruo es capaz de comunicarse, pero la novia, no. Ambos son seres violentos, capaces de matar. Por último, hemos de señalar que tiene gran similitud con el que fue creado para la película La maldición de Frankenstein (T. Fisher, 1965), salvo que en este caso las heridas se han llevado al extremo, logrando hacerlo mucho más repugnante.

En quinto lugar, tenemos el cómic Mary Shelley: la muerte del monstruo (2016), de Raquel Lagartos y Julio César Iglesias; aun sin ser una adaptación de la novela, se nos muestra una imagen del monstruo bastante conseguida. Posee una melena larga, gran altura, un contorno oscuro alrededor de sus ojos, labios negros y cicatrices. En esta ocasión, podemos ver a un monstruo muy sensible e inteligente, sin rencor alguno, que acompańa a Mary Shelley en cada uno de los momentos trágicos de su vida, dejando bien claro que él ha estado siempre ahí cuando algunas 

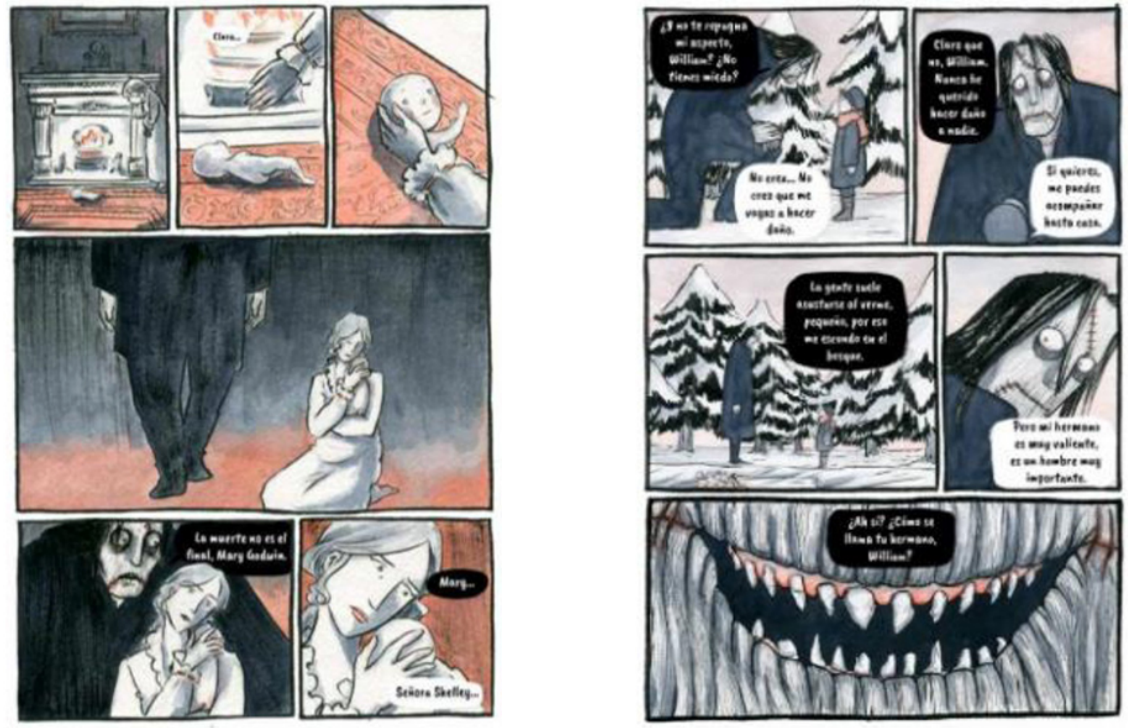

personas le han fallado. Sin duda, es una de las criaturas más conseguidas, podría ser una de las mejores representaciones, en nuestra opinión.

Por último, tendríamos la novela gráfica Gris Grimly's Frankenstein (2015), de Gris Grimly. Tiene una estética de lo más innovadora, ya que se aúnan elementos del propio siglo XVIII con algunos del xix e incluso con otros del xx.

Frankenstein aparece como un hombre desgarbado, con un peinado fuera de lo habitual en las representaciones de este personaje (podría tratarse de un peinado actual). Además, no representa esa belleza humana a la que estamos acostumbrados, más bien es un hombre común. Su delgadez casi enfermiza deja entrever su principal meta, crear vida.

La criatura está representada de una manera que inspira horror, ese horror que sentía todo aquel que lo rechazaba a primera vista por miedo a lo desconocido. Se puede apreciar cómo se le salen los huesos de debajo de la piel, tuberías a las que estaba conectado en el momento de su creación, numerosas cicatrices, labios negros, melena larga y negra, articulaciones más grandes de lo normal y viste con harapos. En cuanto a su personalidad, coincide con alguna de las que ya hemos expuesto anteriormente, se trata de un ser que es inteligente, que busca venganza por el abandono y el no cumplimiento de la promesa realizada por parte de su creador.

Como podemos ver, son numerosas las reinterpretaciones del monstruo y su creador. Algunas de ellas estarán más cerca de la descripción de Mary W. Shelley y otras no tanto, pero sin duda ambos personajes muestran a unos seres que a priori podrían ser diferentes y que acaban siendo más similares de lo que se pudiera llegar a creer. Siempre nos preguntaremos quién es el verdadero monstruo, si el crea- 


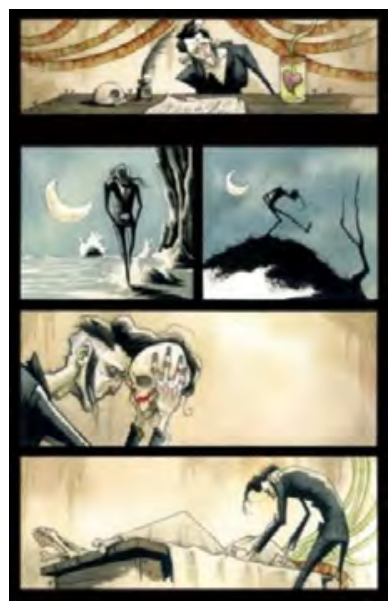

Frankenstein cuando piensa en si crear o no a una compañera para la criatura.

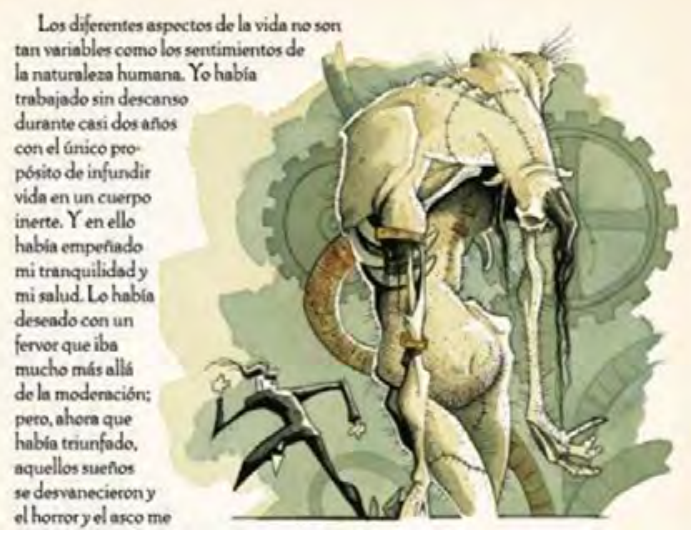

La criatura instantes después de ser creada.
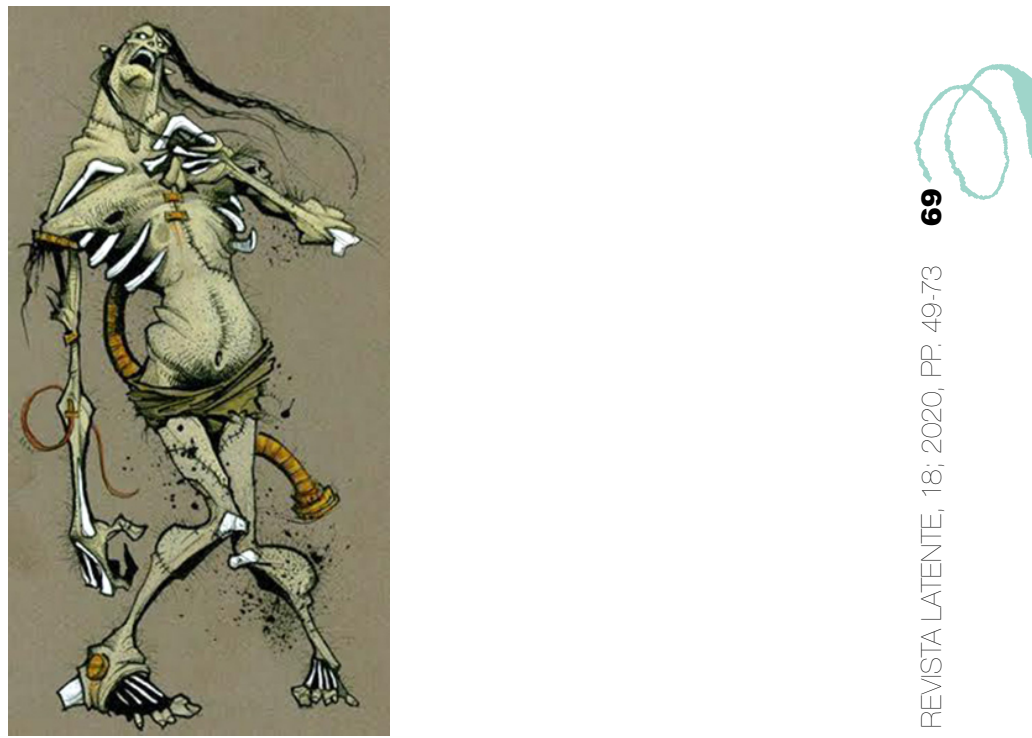

Boceto de la criatura.

dor por engendrar a un ser sin ser consecuente con sus actos o un ser que vino al mundo sin pedirlo, fue rechazado por la humanidad y finalmente decidió vengarse. 


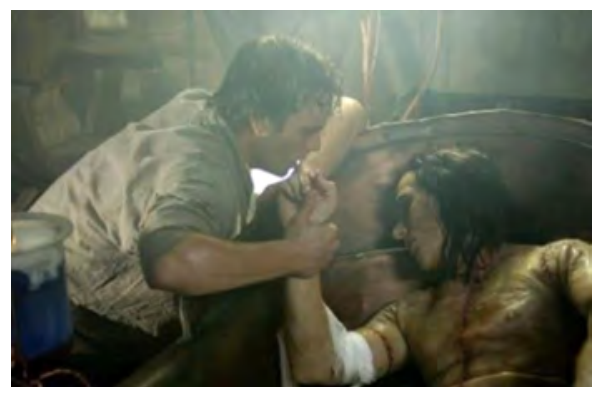

Frankenstein y la criatura en el momento de la creación.

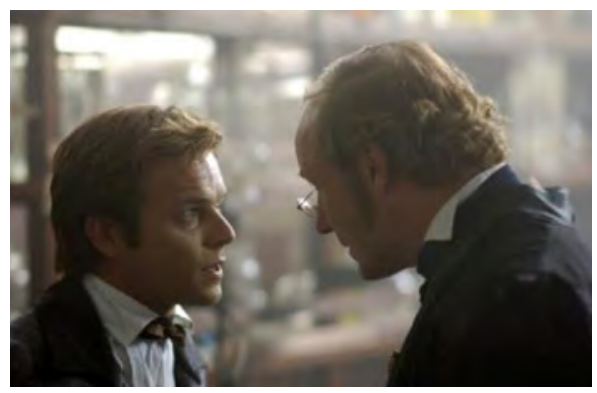

Frankenstein y el doctor Waldman.

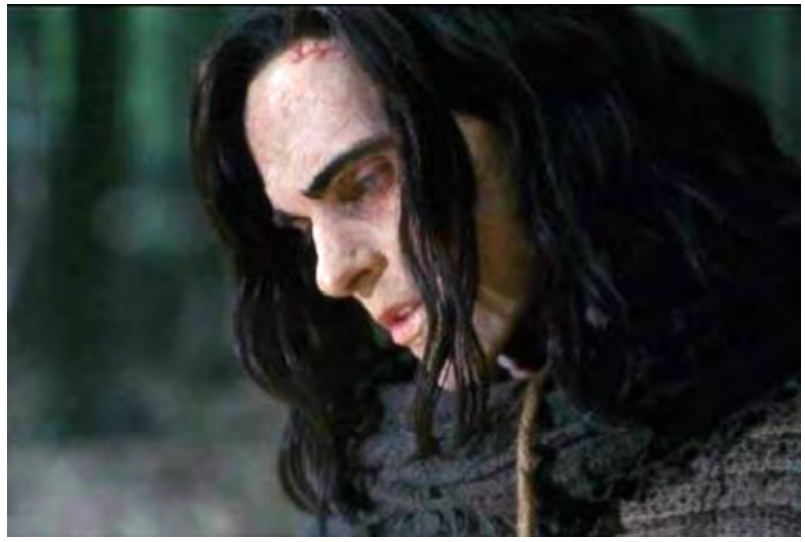

La criatura.

\section{EL MONSTRUO EN LAS SERIES}

En este apartado damos el salto al mundo televisivo de Frankenstein. Por un lado, tendríamos la miniserie Frankenstein (Kevin Connor, EE.UU., 2004). Ambientada en el siglo xix, los personajes visten como en la época, pero, a pesar de ello, al menos en el caso de Frankenstein, su peinado es bastante similar a los que podrían llevarse en la actualidad. Ambos personajes, monstruo y creador, son bastante similares psicológicamente a como se les describe en la novela. Además, físicamente, el primero es bastante similar a su descripción, pero hemos de destacar que no posee unos labios oscuros o que se pueden observar menos heridas e incluso es menos repulsivo que otras versiones de la criatura. 


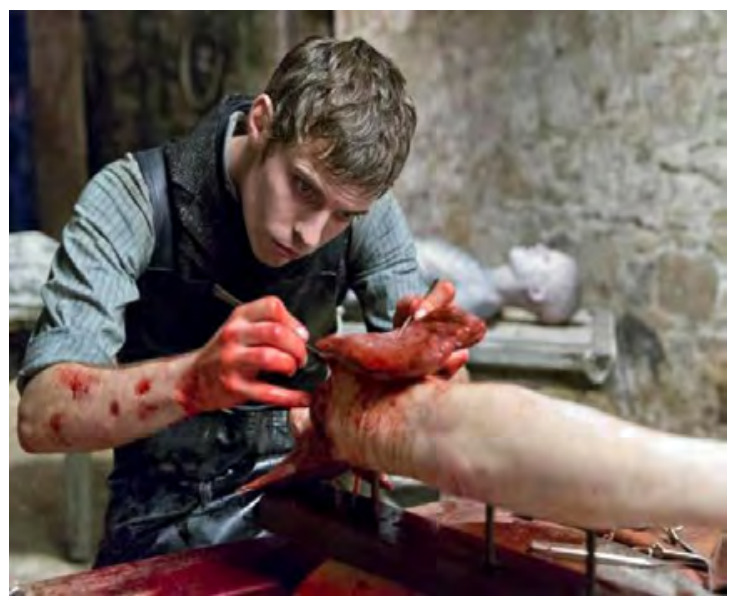

Víctor Frankenstein.

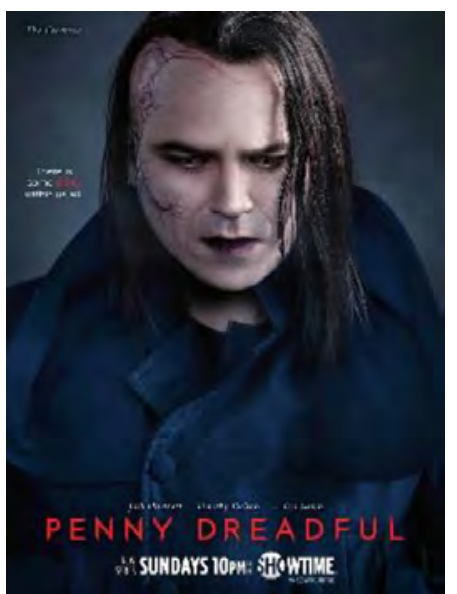

La criatura (John Clare).

Por otro lado, en la serie Penny Dreadful (John Logan, 2014), monstruo y creador tienen matices aún más profundos que cualquiera de los anteriores. Con esto nos referimos a que se hace un análisis más introspectivo de estos dos personajes, conocemos mucho mejor cómo son y cuáles son sus objetivos vitales. No hemos de olvidar que un nombre suele dotar de personalidad al que lo porta y, por ello, es importante que el personaje de la criatura tuviera uno, para así poder tener una identidad, una personalidad clara. El monstruo, en este caso, es mucho más sensible que los demás, le gusta la poesía y sabe apreciar la belleza de las cosas. Además, en nuestra opinión, cumple con todas las características físicas que aporta Mary Shelley en su novela. Recordemos que ha sido creado a partir de un mismo cadáver y no por partes, con lo cual consigue recordar su vida anterior. Sin duda, esto último, junto con la historia que cuenta después de su creación, son los puntos clave que hacen que sea un monstruo de lo más interesante, sin olvidar la esencia del que protagoniza la novela.

Por su parte, el doctor Frankenstein es un ser atormentado, que no puede olvidar el momento de la creación y que ha abandonado a su primera criatura. Como ya señalamos anteriormente, no ceja en su empeño de crear más vida artificial, sin pensar en las consecuencias. Su único afán es romper los límites entre la vida y la muerte. Es un drogadicto que emplea el opio como mecanismo de escape, para no recordar su doloroso pasado. En cuanto a su aspecto físico, podemos observar a un hombre delgado, demacrado por las drogas y siempre ojeroso por las pocas horas de sueño. Esta descripción podría encajar con el último Frankenstein, el enfermizo, que va rozando la recta final hacia la muerte.

Como podemos ver, hay muchísimas representaciones de la criatura y su creador, unas más cercanas a la novela de Mary Shelley y otras se asemejan más a la 
herencia que se ha desarrollado por parte del cine. Sin embargo, ninguna es superior a otra, pues si observamos cada una de las representaciones de estos personajes, pueden reflejar la belleza o, mejor dicho, el canon de belleza de cada una de las épocas en que se han gestado dichos personajes. Por otro lado, hemos de tener en cuenta que cada una de las representaciones realizadas en las diferentes artes son productos totalmente nuevos y no son equivalentes, se aprecia la originalidad, la capacidad de crear algo diferente, aunque partan de la misma esencia.

Recibido: septiembre de 2019; ACEPTADo: noviembre de 2019 


\section{BIBLIOGRAFÍA}

Shelley, W.M. (2018): Frankenstein, Barcelona, Alma Clásicos Ilustrados.

Shelley, M.W. (2009): Frankenstein o el moderno Prometeo, Madrid, Cátedra.

Shelley, M.W. (2011): Frankenstein o el moderno Prometeo, Madrid, Alianza Editorial.

Shelley, M.W. (2017): Frankenstein o el moderno Prometeo. Bicentenario 1818-2018. Edición anotada para cientificos, creadores y curiosos en general, Barcelona, Ariel.

Shelley, M.W. (2017): Edición anotada de Frankenstein (edición, prólogo y notas: Leslie S. Klinger), España, Ediciones Akal, S.A.

Pavés, G.M. y Martín, T. (2018): Frankenstein. Un mito literario en diálogo con la filosofía, las ciencias y las artes, España, Editorial Berenice.

Grimly, G. (2015): Gris Grimly's Frankenstein, Barcelona, Norma Editorial.

Junji Ito (2016): Frankenstein, Barcelona, ECC Ediciones.

Lagartos, R. e Iglesias, J.C. (2016): Mary Shelley: la muerte del monstruo, Madrid, Diábolo Ediciones.

Mousse, M. (2009): Frankenstein de Mary Shelley, Madrid, Ediciones SM.

Sierra, S.A. y Ribas, M. (2009): Frankenstein, Barcelona, Parramón Ediciones.

Powell, M. y Olliffe, P. (2002): Frankenstein. Basado en la novela de Mary Shelley, Barcelona, Norma Editorial.

\section{Películas consultadas}

Frankenstein (Edison Estudios, J.S. Dawley 1910).

Frankenstein (Universal Studios, J. Whale 1931).

Bride of Frankenstein (La novia de Frankenstein) (Universal Studios, J. Whale 1935).

The Curse of Frankenstein (La maldición de Frankenstein) (Hammer Film Productions, T. Fisher 1957).

Frankenstein created woman (Frankenstein creó a la mujer) (Hammer Film Productions, T. Fisher 1967).

Young Frankenstein (El jovencito Frankenstein) (20 ${ }^{\text {th }}$ Century Fox, M. Brooks 1974).

The Bride (La prometida) (Columbia Pictures, F. Roddam 1985).

Remando al viento (Datirambo Films, G. Suárez 1987).

Frankenstein (Frankenstein de Mary Shelley) (American Zoetrope, K. Branagh 1994).

Victor Frankenstein (20 ${ }^{\text {th }}$ Century Fox, P. Mcguigan 2015). 
